\title{
Syntheses, Characterization and DFT Analysis of Two Novel Thiaheterohelicene Derivatives
}

\section{Tetsuji Moriguchi*, Keiichi Mitsumoto, Yuki Nishizawa, Daisuke Yakeya, Venkataprasad Jalli, Akihiko Tsuge}

Department of Applied Chemistry, Faculty of Engineering, Kyushu Institute of Technology, Kitakyushu, Japan

Email: *moriguch@che.kyutech.ac.jp

How to cite this paper: Moriguchi, T., Mitsumoto, K., Nishizawa, Y., Yakeya, D., Jalli, V. and Tsuge, A. (2016) Syntheses, Characterization and DFT Analysis of Two Novel Thiaheterohelicene Derivatives. Crystal Structure Theory and Applications, 5, 63-73. http://dx.doi.org/10.4236/csta.2016.54006

Received: October 27, 2016

Accepted: November 13, 2016

Published: November 16, 2016

Copyright $\odot 2016$ by authors and Scientific Research Publishing Inc. This work is licensed under the Creative Commons Attribution International License (CC BY 4.0).

http://creativecommons.org/licenses/by/4.0/

\section{Open Access}

\begin{abstract}
Two novel thiaheterohelicene derivatives were synthesized from the corresponding 2,2'-(2,6-naphthalenediyl-di-2,1-ethenediyl) bis-thiophene and its dimethyl substituted analogue 2,2'-(2,6-naphthalenediyldi-2,1-ethenediyl) bis-2"-methylthiophene using oxidative photo cyclization reaction. The compounds were characterized by ${ }^{1} \mathrm{H}$ NMR, electron impact-mass spectrometry, elemental analyses, and the absolute molecular structures were determined by single crystal X-ray diffraction analysis. They crystallized under monoclinic system with space group $P 2_{1} / n$ for the unsubstituted compound and $P 2_{1} / c$ for the methyl substituted compound, respectively. The dihedral angle between the terminal thiophene ring and the molecular center was observed to be $20.82^{\circ}$ for the unsubstituted compound and $14.27^{\circ}$ for the methyl substituted compound, respectively. Furthermore, molecules oriented as herringbone structures by intermolecular $\pi-\pi$ stacking in the crystals. The relative study of the actual arrangement of these molecules has been carried out using X-ray diffraction analysis. The two molecules have different crystal packing. The molecule $3 \mathrm{~b}$ has herring bone like arrangement due to the substituent bulkiness and weak $\mathrm{CH}-\pi$ interaction. On the other hand, the molecular packing of molecule $3 \mathrm{a}$ is not herringbone probably due to the multiple weak intermolecular $\mathrm{CH}$-S short contacts between columns consisting of stacked molecules.
\end{abstract}

\section{Keywords}

Crystal Structure, Thiaheterohelicene Derivative, Strained Structure, Single Crystal X-Ray Study

\section{Introduction}

Helicenes are ortho fused polycyclic aromatic compounds. They have attracted great 
attention of researchers because of the unique properties associated with their structure. Helicenes have found many applications in various fields such as organic electronic materials [1] [2], liquid crystals [3] [4] and molecular recognition [5] [6] [7]. There are two classes of helicenes, carbohelicene and heterohelicene. Although the carbohelicenes are more studied, recently heterohelicene molecules having one or more heteroatom have also gained great attention due to the extended $\pi$-electron conjugation compared with carbohelicene. They have been employed as organic light-emitting diodes [8], organic field effect transistors [9] [10] and photovoltaics [11]. Over the past decade intense efforts have been made for the synthesis of novel heterohelicene molecules comprising oxygen [12] [13] [14], sulfur [15] [16] [17] [18] and boron [19] as a heteroatom. Linear fused thiahelicene molecules exhibit good organic field effect transistor (OFET) mobility, easier functionalization and better chemical stability. As part of our continuous interest towards the development of novel polycyclic compounds as semiconductive materials, herein, we report the syntheses of two new thiahelicene derivatives having $\mathrm{H}(3 \mathbf{a})$ and $-\mathrm{CH}_{3}(\mathbf{3} \mathbf{b})$ substituents at $\boldsymbol{\alpha}$ position to the $\mathrm{S}$ atom. The aim of this research is to study the effect of the $-\mathrm{CH}_{3}$ substitution on the actual arrangement of the molecules using X-ray structural determination of the two molecules. We have taken $-\mathrm{CH}_{3}$ substituent for the comparative study of the effect of substation on the actual arrangement of these molecules because making of this molecule (3b) is easy, economically cheaper compared to the other substituents.

\section{Experimental}

\subsection{Materials and Measurements}

All reagents and solvents were purchased from commercial sources and are used without further purification. The ${ }^{1} \mathrm{H}-\mathrm{NMR}$ spectrum was recorded on a JEOL JNM A-500 spectrometer in $\mathrm{CDCl}_{3}$ with tetramethylsilane $\left(\mathrm{Me}_{4} \mathrm{Si}\right)$ as the internal reference. The electron impact (EI) mass spectrum (MS) of the compound was obtained on a JEOL JMS-SX102A spectrometer using dichloromethane (DCM) as the solvent. The instrument was operated in positive ion mode over an $\mathrm{m} / \mathrm{z}$ range of $100-1200$. Elemental analysis was performed on a YANAKO MT-5 CHN analyzer.

\subsection{Synthesis}

\section{Typical procedure for the synthesis of the compounds $2 a$ and $2 b$.}

2,6-Bis(triphenylphosphinnomethyl)-naphthalene dichloride Wittig Salt (0.75 g, 1.0 mmol) 1 was dissolved in $200 \mathrm{ml}$ of dry THF in round bottom flask under argon stream. To this thiophene carboxaldehydes $(2.0 \mathrm{mmol})$ was added dropwise, the mixture was stirred for $14 \mathrm{~h}$, quenched with $1.0 \% \mathrm{HCl}$ aq., and extracted twice with $\mathrm{CH}_{2} \mathrm{Cl}_{2}$. The organic layers were washed once with $50 \mathrm{~mL}$ water, twice with $50 \mathrm{~mL}$ of brine solution, dried over $\mathrm{MgSO}_{4}$, and the solvent was removed under reduced pressure. The precursor $\mathbf{2} \mathbf{a}$ and $\mathbf{2} \mathbf{b}$ were obtained using silica gel (Wako gel C-300) column chromatography (280 mg, $82 \%$ yield for $2 \mathrm{a}, 270 \mathrm{mg}, 72 \%$ for $2 \mathrm{~b}$ ) with $\mathrm{CH}_{2} \mathrm{Cl}_{2}$ as an eluent.

$2 \mathrm{a}^{1} \mathrm{H}$ NMR (400 MHz, $\left.\mathrm{CDCl}_{3}\right): 7.04(\mathrm{~d}, 2 \mathrm{H}, J=8.0 \mathrm{~Hz}$, ethenyl $\mathrm{H}), 7.05(\mathrm{~d}, 2 \mathrm{H}, J=$ 
$7.0 \mathrm{~Hz}$, aryl H), 7.12 (s, 2H, aryl H), $7.22(\mathrm{~d}, 2 \mathrm{H}, J=7.0 \mathrm{~Hz}$, aryl H), $7.36(\mathrm{~d}, 2 \mathrm{H}, J=8.0$ $\mathrm{Hz}$, ethenyl H), 7.67 (d, $4 \mathrm{H}, J=6.6 \mathrm{~Hz}$, aryl H), 7.78 (t, 2H, $J=6.6 \mathrm{~Hz}$, aryl H); EI-MS: $\mathrm{m} / z 344\left(\mathrm{M}^{+}\right)$.

2b ${ }^{1} \mathrm{H}$ NMR (400 MHz, $\left.\mathrm{CDCl}_{3}\right): 2.50\left(6 \mathrm{H}, \mathrm{s}, \mathrm{CH}_{3}\right), 6.66(\mathrm{~d}, 2 \mathrm{H}, J=7.7 \mathrm{~Hz}$, ethenyl H), $6.90(\mathrm{~d}, 2 \mathrm{H}, J=7.7 \mathrm{~Hz}$, ethenyl H), 6.95 (d, 2H, $J=7.4 \mathrm{~Hz}$, aryl H), 7.25 (d, 2H, $J=7.4$ $\mathrm{Hz}$, aryl H), 7.63 (d, $2 \mathrm{H}, J=7.2 \mathrm{~Hz}$, aryl H), 7.74 (s, 2H, aryl H), 7.75 (d, 2H, J= 7.2 $\mathrm{Hz}$, aryl H); EI-MS: $m / z 372\left(\mathrm{M}^{+}\right)$.

Typical procedure for the Photo cyclization of the compounds $2 \mathrm{a}$ and $2 \mathrm{~b}$.

4,9-Bis $\{2$ '-(2"-substituted thiophenyl)ethenyl $\}$-naphthalene (1.0 mmol) 2 was dissolved in $200 \mathrm{ml}$ of benzene in round bottom flask. To this iodine $(10 \mathrm{mmol})$ was added, the mixture was stirred and irradiated UV light using high-pressure Hg lump for $14 \mathrm{~h}$, quenched with $1.0 \mathrm{~mol} / \mathrm{L} \mathrm{Na}_{2} \mathrm{~S}_{2} \mathrm{O}_{3}$ solution, allowed to warm to room temperature, and extracted twice with AcOEt. The organic layers were washed once with $50 \mathrm{~mL}$ water, twice with $50 \mathrm{~mL}$ of brine solution, dried over $\mathrm{MgSO}_{4}$, and the solvent was removed under reduced pressure. The title compound was obtained using silica gel (Wako gel C-300) column chromatography (190 mg, 56\% yield for 3a, $120 \mathrm{mg}, 33 \%$ for 3b) with $\mathrm{CH}_{2} \mathrm{Cl}_{2}$ as an eluent.

3a M.p.: $226^{\circ} \mathrm{C}-232^{\circ} \mathrm{C}$; ${ }^{1} \mathrm{H} \operatorname{NMR}\left(400 \mathrm{MHz}, \mathrm{CDCl}_{3}\right.$ ): 7.68 (d, $2 \mathrm{H}, J=7.3 \mathrm{~Hz}$, aryl H), $7.87(\mathrm{~d}, 2 \mathrm{H}, J=7.5 \mathrm{~Hz}$, aryl H), $8.02(\mathrm{~d}, 2 \mathrm{H}, J=7.2 \mathrm{~Hz}$, aryl H), 8.05 (d, 2H, $J=7.3 \mathrm{~Hz}$, aryl $\mathrm{H}), 8.54(\mathrm{~d}, 2 \mathrm{H}, J=7.2 \mathrm{~Hz}$, aryl H), $9.04(\mathrm{~d}, 2 \mathrm{H}, J=7.5 \mathrm{~Hz}$, aryl H); EI-MS: $m / z$ $340\left(\mathrm{M}^{+}\right)$; Analysis: $\mathrm{C}_{22} \mathrm{H}_{12} \mathrm{~S}_{2}$, Found: C: $77.74 \%, \mathrm{H}: 3.61 \%$, Calculated: C: $77.61 \%, \mathrm{H}$ : $3.55 \%)$.

3b M.p.: $232^{\circ} \mathrm{C}-236^{\circ} \mathrm{C} ;{ }^{1} \mathrm{H}$ NMR $\left(400 \mathrm{MHz}, \mathrm{CDCl}_{3}\right): 2.80$ (s, 6H, $\left.\mathrm{CH}_{3}\right), 7.85$ (d, $2 \mathrm{H}, J$ $=7.3 \mathrm{~Hz}$, aryl H), $8.00(\mathrm{~d}, 2 \mathrm{H}, J=7.3 \mathrm{~Hz}$, aryl H), $8.04(\mathrm{~d}, 2 \mathrm{H}, J=7.4 \mathrm{~Hz}$, aryl H), 8.26 (s, 2H, aryl H), $9.06\left(\mathrm{~d}, 2 \mathrm{H}, J=7.4 \mathrm{~Hz}\right.$, aryl H); EI-MS: $m / z 368\left(\mathrm{M}^{+}\right)$; Analysis: $\mathrm{C}_{24} \mathrm{H}_{16} \mathrm{~S}_{2}$, Found: C: $78.34 \%, \mathrm{H}: 4.49 \%$, Calculated: C: $\left.78.22 \%, \mathrm{H}: 4.38 \%\right)$.

\subsection{Single Crystal X-Ray Analysis and Structure Determination}

Single crystals of two compounds $3 \mathrm{a}$ and $3 \mathrm{~b}$ were obtained at room temperature from a solution of dichloromethane/n-hexane $(v / v=1 / 1)$.

The crystal data were recorded on a Bruker APEX II KY CCD diffractometer equipped with graphite monochromatized (doubly curved silicon crystal) Mo-K $\alpha$-radiation $(\lambda=$ $0.71073 \AA$ ) from a sealed micro focus tube, and a nominal crystal to area detector distance of $58 \mathrm{~mm}$. X-ray generator settings were $50 \mathrm{kV}$ and $30 \mathrm{~mA}$. The data were collected at $-183^{\circ} \mathrm{C}(90 \mathrm{~K})$. Data were acquired using four sets of Omega scans at different Phi settings and the frame width was $0.5^{\circ}$. APEX2 software was used for the preliminary determination of the unit cell [20]. Integrated intensities and unit cell refinement were determined using the SAINT program [21]. Integration of the data yielded a total of 15,805 reflections to a maximum $\theta$ angle of $28.67^{\circ}$ ( $0.74 \AA$ resolution) for the compound 3a. And a total of 7585 reflections to a maximum $\theta$ angle of $25.55^{\circ}(0.82 \AA$ resolution) for the compound $3 \mathrm{~b}$.

The average residual for symmetry equivalent reflections were $R_{\mathrm{int}}=4.13 \%$ with $R_{\sigma}=$ 
$3.62 \%$ for $3 \mathrm{a}$ and $R_{\text {int }}=4.81 \%$ with $R_{\sigma}=3.85 \%$ for $3 \mathrm{~b}$, respectively. XPREP [22] determined the space groups to be $P 2_{1} / n$ (No. 14) with $\mathrm{Z}=4$ for the formula moiety of $3 \mathrm{a}$, $\mathrm{C}_{22} \mathrm{H}_{12} \mathrm{~S}_{2}$, and $P 2_{1} / c$ (No. 14) with $\mathrm{Z}=2$ for the formula moiety of $3 \mathrm{~b}, \mathrm{C}_{24} \mathrm{H}_{16} \mathrm{~S}_{2}$.

Several scans in the $\omega$ direction were made to increase the number of redundant reflections, which were averaged in the refinement cycles. This procedure replaces an empirical absorption correction [23]. The structures were solved with direct methods (SHELXS-2014) and refined against $F^{2}$ (SHELXL-2014) [24].

Hydrogen atoms at carbon atoms were added geometrically and refined using a riding model (constrained), whereas the hydrogen atoms at carbon atoms were exact localized and refined isotropically with bond restraints of $89 \mathrm{pm}$ for C-H. All non-hydrogen atoms were refined with anisotropic displacement parameters.

\section{Results and Discussion}

Synthetically, the two desired compounds $\mathbf{3 a}$ and $\mathbf{3 b}$ were obtained in $70 \%$ isolated yield from the corresponding precursors bis(substituted-thienylethenyl) naphthalenes $2 \mathbf{a}$ and $\mathbf{2} \mathbf{b}$ by oxidative photo cyclization reaction in the presence of iodine as an oxidative reagent (Scheme 1). Structural properties in solution are in line with expectations, as shown by NMR spectroscopy. For the compounds $\mathbf{3 a}$ and $\mathbf{3 b}$, the four protons $(\mathrm{Ha}$ and $\mathrm{Hb}$ ), which located in Fjord regions were observed at low magnetic field region. The NMR shift values are $8.54 \mathrm{ppm}$ and $9.04 \mathrm{ppm}$ for $3 \mathrm{a}, 8.26 \mathrm{ppm}$ and $9.06 \mathrm{ppm}$ for $3 \mathrm{~b}$, respectively. The shifts were well explained by the strong ring current effects of the $\pi$-systems on the molecules.

The exact molecular structures of the compounds $3 \mathbf{a}$ and $\mathbf{3 b}$ are determined by using $\mathrm{X}$-ray diffraction analysis (Figure 1, Figure 2). Suitable single crystals for X-ray structure analyses were obtained for the products $\mathbf{3 a}$ and $\mathbf{3 b}$ in dichloromethane/n-hexane $(v / v=1 / 1)$. The crystallographic details are summarized in Table 1 . The compound 3a crystallizes in the centrosymmetric space group $P 2_{1} / n$ (No.14) with two non-planar<smiles>[R]c1ccc(/C=C/c2ccc3cc(/C=C/c4ccc(/C=C/c5ccc([R])s5)s4)ccc3c2)s1</smiles>

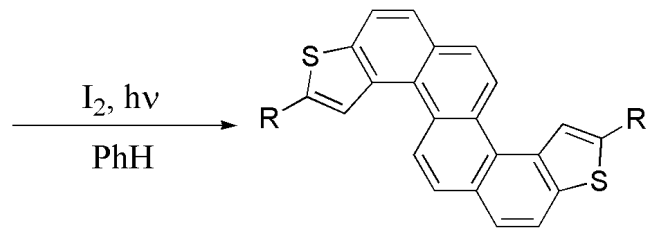

$$
\begin{aligned}
& \mathbf{3 a} ; \mathrm{R}=\mathrm{H} \\
& \mathbf{3 b} ; \mathrm{R}=\mathrm{CH}_{3}
\end{aligned}
$$

Scheme 1. Synthesis of the title compounds $3 a$ and $3 b$. 

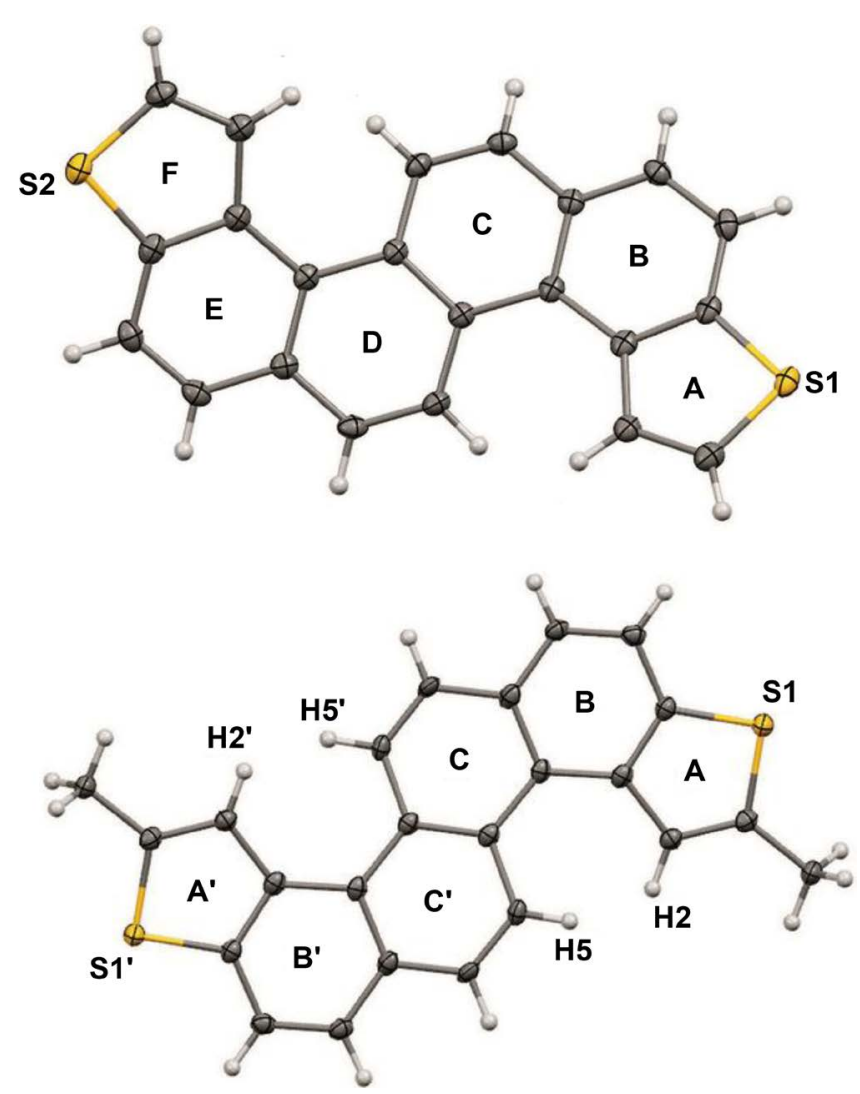

Figure 1. Molecular structures of compounds $3 \mathbf{a}$ (above) and $\mathbf{3 b}$ (below).
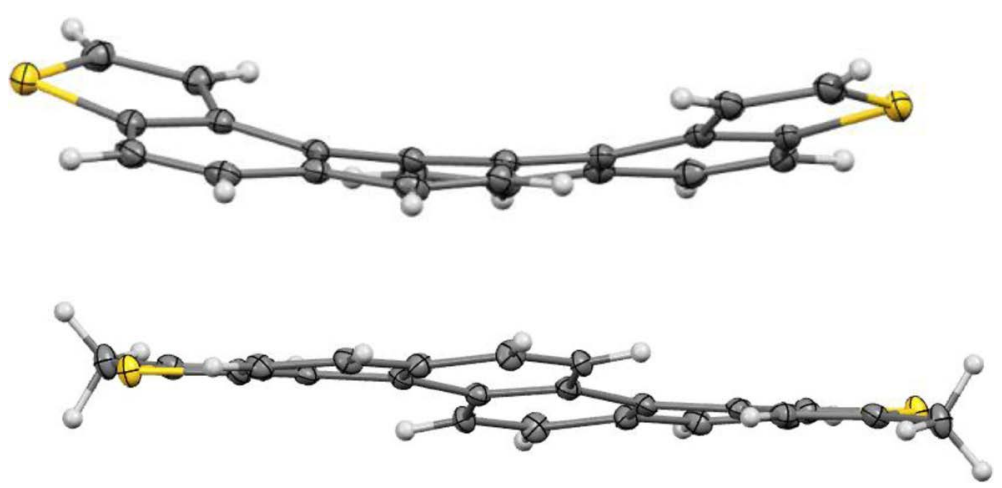

Figure 2. Side view of structures of the compounds $3 a$ (above) below (3b).

molecules in the unit cell (Figure 3). As the molecular shape was strained, the dihedral angle between two terminal thiophene rings was quite large $\left(37.83^{\circ}\right)$. On the other hand, the compound $\mathbf{3 b}$ also crystallizes in the centrosymmetric space group $P 2_{1} / c$ (No.14) with four non-planar molecules in the unit cell (Figure 3). The molecular shape was also strained, the two terminal thiophene rings are parallel (the dihedral angle between them is $0^{\circ}$ ).

Furthermore, the molecular packing of the compound $\mathbf{3 a}$ and $\mathbf{3 b}$ in the crystals were quite different. The packing of $\mathbf{3 b}$ is called "Herring-Bone" structure. In general, almost organic semiconductive compounds consisting of polynuclear aromatic hydrocarbons 
and polynuclear heteroaromatics usually form two-dimensional herringbone molecular orientation in crystal. On the contrary, packing style of $\mathbf{3 a}$ is not "Herring-Bone" structure. Difference between crystal packing of $\mathbf{3 a}$ and $\mathbf{3 b}$, is probably due to the substituent bulkiness and weak $\mathrm{CH}-\pi$ interaction. In the crystal of $3 \mathrm{a}$, multiple weak intermolecular $\mathrm{CH}-\mathrm{S}$ short contacts are existed between columns consisting of stacked molecules (Figure 4). In detail sulfur atoms on one molecule and aromatic protons on neighbor molecule, and the distance is $2.971 \AA$. On the other hand, such weak interaction could not be observed in the crystal of $\mathbf{3 b}$. Only van der Waals forces are not existed between columns consisting of stacked molecules.

HOMO and LUMO energy level calculations of the $\pi$ systems of the compounds were carried out using density functional theory (DFT) B3-LYP 6-31G(d) level on SPARTAN14 Suite program [18]. Atomic coordinate data $(x, y, z)$ of the X-Ray analyses were used in calculations. The calculation results were HOMO $-5.93 \mathrm{eV}$ LUMO -1.93 $\mathrm{eV}$ for $3 \mathrm{a}$ and HOMO $-6.95 \mathrm{eV}$ LUMO $2.13 \mathrm{eV}$ for $\mathbf{3 b}$, respectively. The energy gaps were significantly large ( $4.00 \mathrm{eV}$ for $3 \mathrm{a}$ and $9.00 \mathrm{eV}$ for $3 \mathbf{b}$ ). The large difference between the two energy levels is probably due to the molecular structures in the crystal packing.

Table 1. Crystal data and structure refinement details for compounds $\mathbf{3 a}$ and $\mathbf{3 b}$.

\begin{tabular}{|c|c|c|}
\hline Empirical Formula & $\mathrm{C}_{22} \mathrm{H}_{12} \mathrm{~S}_{2}$ & $\mathrm{C}_{24} \mathrm{H}_{16} \mathrm{~S}_{2}$ \\
\hline Formula Weight & 340.44 & 368.49 \\
\hline Temperature & $90 \mathrm{~K}$ & $90 \mathrm{~K}$ \\
\hline Crystal size & $0.30 \times 0.20 \times 0.15 \mathrm{~mm}$ & $0.20 \times 0.15 \times 0.10 \mathrm{~mm}$ \\
\hline Crystal color & Yellow & Yellow \\
\hline Crystal system & Monoclinic & Monoclinic \\
\hline Space group & $P 2_{1} / n($ No. 14$)$ & $P 2_{1} / c($ No. 14$)$ \\
\hline a & $\mathrm{a}=13.873(4) \AA$ & $\mathrm{a}=5.5102(15) \AA$ \\
\hline $\mathrm{b}$ & $\mathrm{b}=3.8474(11) \AA$ & $\mathrm{b}=6.5517(18) \AA$ \\
\hline c & $c=27.800(8) \AA$ & $c=22.431(6) \AA$ \\
\hline$\beta$ & $90.605(3)^{\circ}$ & $98.727(9)^{\circ}$ \\
\hline Limiting indices & $\begin{array}{l}-17 \leq h \leq 18,-5 \leq k \leq 5, \\
-36 \leq 1 \leq 35\end{array}$ & $\begin{array}{l}-17 \leq h \leq 18,-5 \leq k \leq 5, \\
-36 \leq 1 \leq 35\end{array}$ \\
\hline Volume & $1483.7(7) \AA^{3}$ & $809.2(4) \AA^{3}$ \\
\hline $\mathrm{Z}$ & 4 & 2 \\
\hline Calculated density & $1.524 \mathrm{~g} / \mathrm{cm}^{-1}$ & $1.512 \mathrm{~g} / \mathrm{cm}^{-1}$ \\
\hline Reflection collected/unique & $15805 / 3572[R(\mathrm{int})=0.0413]$ & $7585 / 1513[R(\mathrm{int})=0.0481]$ \\
\hline$\theta$ range for data collection & $\theta_{\max }=28.67^{\circ}, \theta_{\min }=1.47^{\circ}$ & $\theta_{\max }=25.55^{\circ}, \theta_{\min }=1.82^{\circ}$ \\
\hline data completeness & $93.6 \%$ & $99.7 \%$ \\
\hline Absorption coefficient & $0.357 \mathrm{~mm}^{-1}$ & $0.334 \mathrm{~mm}^{-1}$ \\
\hline $\mathrm{F}(000)$ & 704 & 384 \\
\hline Absorption correction & Empirical & Empirical \\
\hline Refinement method & Full-matrix LS on $F^{2}$ & Full-matrix LS on $F^{2}$ \\
\hline Data/restraints/parameters & $3572 / 0 / 217$ & $1513 / 0 / 119$ \\
\hline Goodness-of-fit on $F^{2}$ & 1.048 & 1.160 \\
\hline Final $R$ indices $[\mathrm{I}>2 \operatorname{sigma}(\mathrm{I})]$ & $R_{1}=0.0399$ & $R_{1}=0.0495$ \\
\hline $\mathrm{w} R_{2}$ indices (all data) & $\mathrm{w} R_{2}=0.1037$ & $\mathrm{w} R_{2}=0.1195$ \\
\hline Largest diff. peak and hole $\left(\mathrm{e} \AA^{-3}\right)$ & 0.407 and -0.333 & 0.347 and -0.286 \\
\hline
\end{tabular}



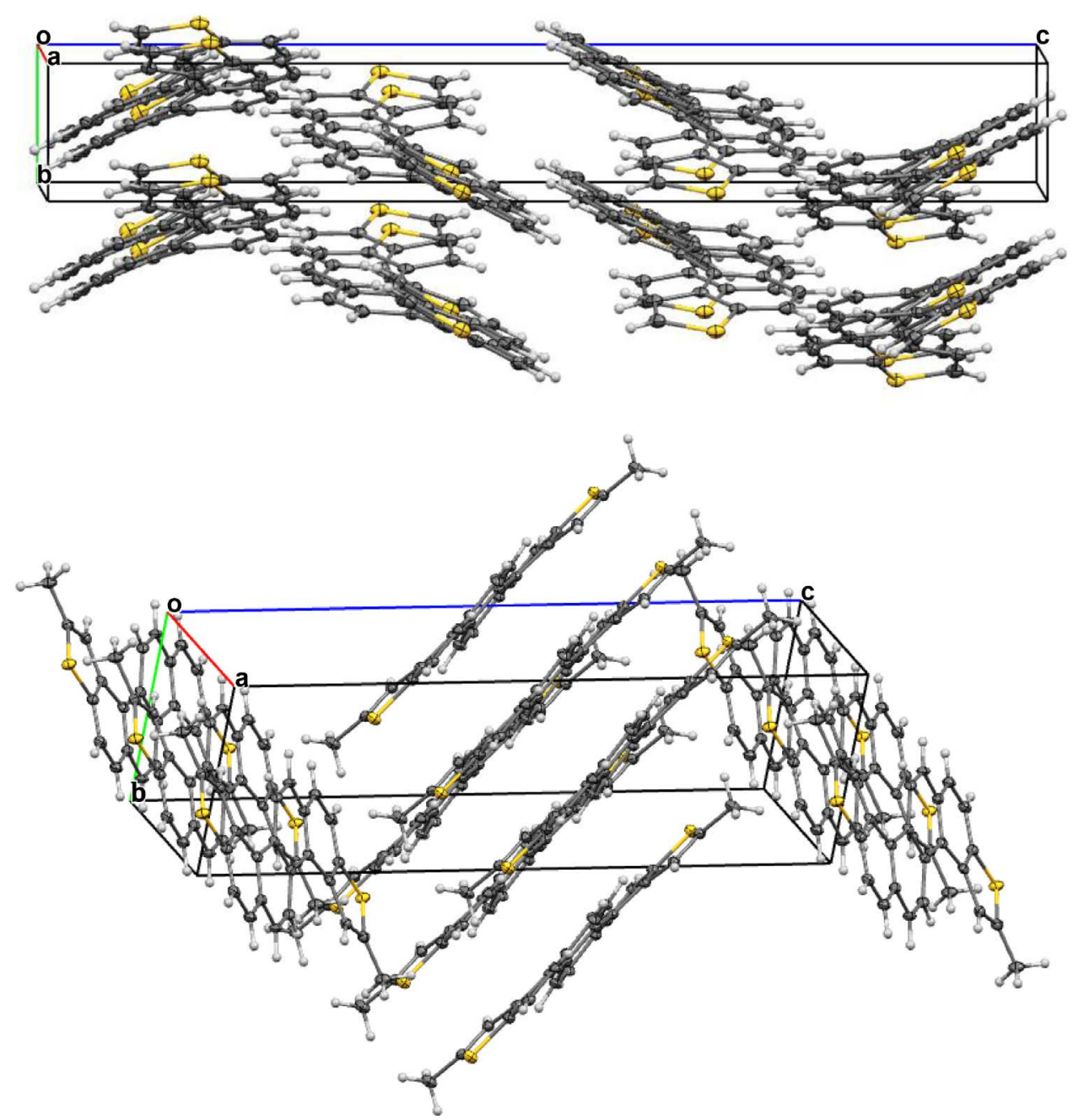

Figure 3. Molecular packing of compounds 3a (above) below (3b).

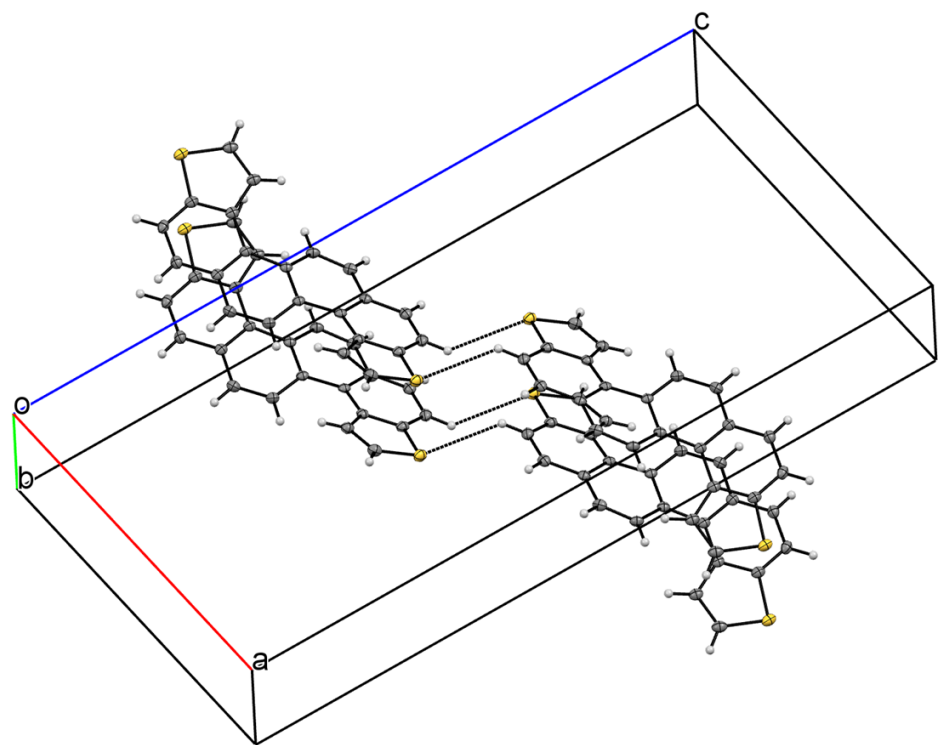

Figure 4. Intermolecular short contact diagram of molecule 3a. 
On the other hand, we also performed molecular calculations of these compounds $3 \mathrm{a}$ and $\mathbf{3 b}$ to compare with $\mathrm{X}$-ray results (Figure 5). In molecular calculations, atomic coordinate data $(x, y, z)$ were calculated using MMFF94 (Merck Molecular Force Field 94) program [25]. The resulting molecular structures are shown in Figure 6. The obtained molecular shapes are slightly different compared with those of the molecules in crystals. This implies that the molecules in the crystals are almost not affected by crystal packing force and many weak interactions such as $\pi-\pi$ interaction, $\mathrm{CH}-\pi$ interaction, and so on.

From the calculated results, we also obtained HOMO and LUMO energy levels, HOMO $-5.44 \mathrm{eV}$ LUMO $-1.36 \mathrm{eV}$ for 3a and HOMO $-5.20 \mathrm{eV}$ LUMO $1.33 \mathrm{eV}$ for $3 \mathbf{b}$, respectively. The values are slightly different from those of the molecules in crystals, and these differences are probably due to the molecular structures. From the results the compounds $\mathbf{3 a}$ and $\mathbf{3 b}$ are seems to be good $p$-type semiconducting materials.

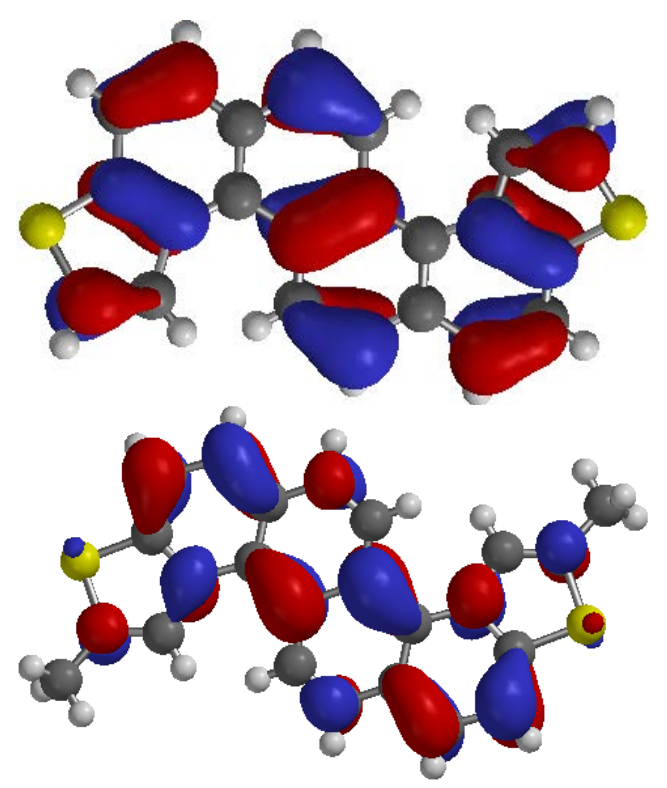

Figure 5. HOMO orbitals in the crystals of the compounds $3 \mathbf{a}$ (above) and $\mathbf{3 b}$ (below).
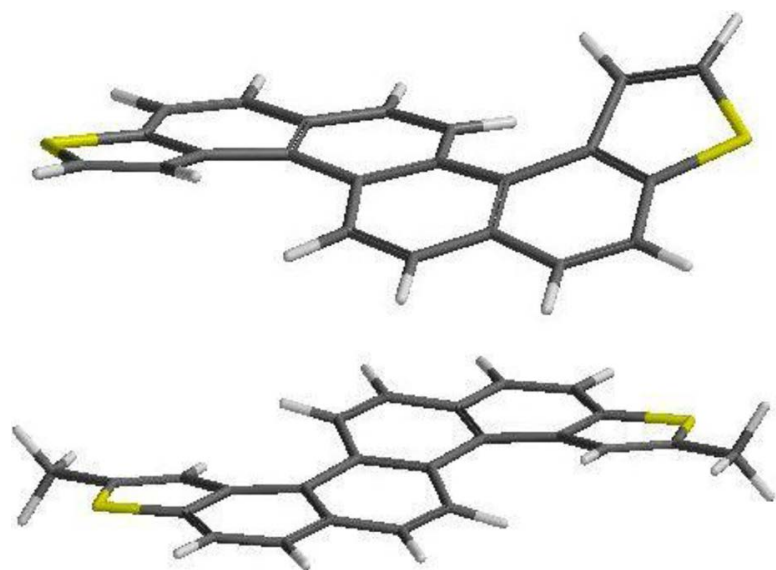

Figure 6. Calculated molecular structures of the compounds $\mathbf{3 a}$ (above) and $\mathbf{3 b}$ (below). 
Furthermore, UV visible and fluorescence spectra were acquired to determine the photochemical properties of the two compounds $3 \mathrm{a}$ and $\mathbf{3 b}$. The strong emissions were observed for the compounds $\mathbf{3 a}$ and $\mathbf{3 b}$ in chloroform and the peak maxima are detected at $405 \mathrm{~nm}$ for $3 \mathrm{a}$ and $403 \mathrm{~nm}$ for $3 \mathrm{~b}$, respectively. The strong emissions can be explained by the molecular shapes of the compounds $\mathbf{3 a}$ and $\mathbf{3 b}$. In another words, the compounds have no flexible parts, therefore, the excited energy cannot be relaxed through molecular vibrations.

\section{Conclusion}

The novel air stable thiaheterohelicene derivatives were prepared in high yield and characterized by ${ }^{1} \mathrm{H}$ NMR, elemental analyses and electron impact-mass spectrometry. The exact molecular structures and the molecular packing of the compounds were confirmed by single crystal X-ray analyses. The crystal packing was the same styles as other semiconductor compounds. Therefore, the semiconducting properties of these compounds are under investigation now.

\section{Acknowledgements}

We are grateful to the Center for Instrumental Analysis, Kyushu Institute of Technology (KITCIA), for elemental analyses, mass spectra and ${ }^{1}$ NMR spectra, and X-ray analyses. We also thank Dr. Kenji Yoza (Bruker AXS JAPAN) for experimental assistance during the refinements of the X-ray analyses. This research was financially supported by Kitakyushu Foundation for the Advancement of Industry Science and Technology (FAIS) and JSPS KAKENHI Grant Number 15K05611.

\section{References}

[1] Storch, J., Zadny, J., Strasak, T., Kubala, M., Sykora, J., Dusek, M., Cirkva, V., Matejka, P., Krbal, M. and Vacek, J. (2015) Synthesis and Characterization of a Helicene-Based Imidazolium Salt and Its Application in Organic Molecular Electronics. Chemistry-A European Journal, 21, 2343-2347. https:/doi.org/10.1002/chem.201405239

[2] Field, J.E., Muller, G., Riehl, J.P. and Venkataraman, D. (2003) Circularly Polarized Luminescence from Bridged Triarylamine Helicenes. Journal of the American Chemical Society, 125, 11808-11809. https:/doi.org/10.1021/ja035626e

[3] Nuckolls, C., Shao, R., Jang, W.G., Clark, N.A., Walba, D.M. and Katz, T.J. (2002) ElectroOptic Switching by Helicene Liquid Crystals. Chemistry of Materials, 14, 773-776. https:/doi.org/10.1021/cm0106280

[4] Nuckolls, C. and Katz, T.J. (1998) Synthesis, Structure, and Properties of a Helical Columnar Liquid Crystal. Journal of the American Chemical Society, 120, 9541-9544. https:/doi.org/10.1021/ja982025s

[5] Wang, D.W. and Katz, T.J. (2005) A [5]HELOL Analogue That Senses Remote Chirality in Alcohols, Phenols, Amines and Carboxylic Acids. The Journal of Organic Chemistry, 70, 8497-8502. https:/doi.org/10.1021/jo0512913

[6] Nuckolls, C., Katz, T.J., Verbiest, T., Elshocht, S.V., Kuball, H.G., Kiesewalter, S., Lovinger, A.J. and Persoons, A. (1998) Circular Dichroism and UV-Visible Absorption Spectra of the Langmuir-Blodgett Films of an Aggregating Helicene. Journal of the American Chemical 
Society, 120, 8656-8660. https:/doi.org/10.1021/ja981757h

[7] Yamamoto, K., Ikeda, T., Kitsuki, T., Okamoto, Y., Chikamatsu, H. and Nakazaki, M. (1990) Synthesis and Chiral Recognition of Optically Active Crown Ethers Incorporating a Helicene Moiety as the Chiral Centre. Journal of the Chemical Society, Perkin Transactions., 1, 271-276. https:/doi.org/10.1039/p19900000271

[8] Tsuji, H., Mitsui, C., Ilies, L., Sato, Y. and Nakamura, E. (2007) Synthesis and Properties of 2,3,6,7-Tetraarylbenzo[1,2- $b: 4,5-b$ ']difurans as Hole-Transporting Material. Journal of the American Chemical Society, 129, 11902-11903. https:/doi.org/10.1021/ja074365w

[9] Mitsui, C., Soeda, J., Miwa, K., Tsuji, H., Takeya, J. and Nakamura, E. (2012) Naphtho[2,1-b:6,5-b']difuran: A Versatile Motif Available for Solution-Processed Single-Crystal Organic Field-Effect Transistors with High Hole Mobility. Journal of the American Chemical Society, 134, 5448-5451. https:/doi.org/10.1021/ja2120635

[10] Nakano, M., Niimi, K., Miyazaki, E., Osaka, I. and Takimiya, K. (2012) Isomerically Pure Anthra[2,3-b:6,7-b']-difuran (anti-ADF), -dithiophene (anti-ADT), and -diselenophene (anti-ADS): Selective Synthesis, Electronic Structures, and Application to Organic FieldEffect Transistors. The Journal of Organic Chemistry, 77, 8099-8111. https:/doi.org/10.1021/jo301438t

[11] Wu, J.-S., Lin, C.-T., Wang, C.-L., Cheng, Y.-J. and Hsu, C.-S. (2012) New Angular-Shaped and Isomerically Pure Anthradithiophene with Lateral Aliphatic Side Chains for Conjugated Polymers: Synthesis, Characterization, and Implications for Solution-Prossessed Organic Field-Effect Transistors and Photovoltaics. Chemistry of Materials, 24, 2391-2399. https:/doi.org/10.1021/cm301176s

[12] Areephong, J., Ruangsupapichart, N. and Thongpanchang, T. (2004) Enantioselective Bioreduction of Ethyl 4,4,4-Trihalide-3-oxobutanoate by Kluyveromyces marxianus. Tetrahedron Letters, 45, 3067-3070. https:/doi.org/10.1016/j.tetlet.2004.02.105

[13] Salim, M., Akutsu, A., Kimura, T., Minabe, M. and Karikomi, M. (2011) Novel Synthesis of Oxa[9] helicenes by Lawesson's Reagent-Mediated Cyclization of Helical Quinone Derivatives. Tetrahedron Letters, 52, 4518-4520. https:/doi.org/10.1016/j.tetlet.2011.06.033

[14] Irie, R., Tanoue, A., Urakawa, S., Imahori, T., Igawa, K., Matsumoto, T., Tomooka, K., Kikuta, S., Uchida, T. and Katsuki, T. (2011) Synthesis and Stereochemical Behavior of a New Chiral Oxa[7]heterohelicene. Chemistry Letters, 40, 1343-1345.

https:/doi.org/10.1246/cl.2011.1343

[15] Roncali, J. (1992) Conjugated Poly(thiophenes): Synthesis, Functionalization, and Applications. Chemical Reviews, 92, 711-738. https:/doi.org/10.1021/cr00012a009

[16] Roncali, J. (1997) Synthetic Principles for Bandgap Control in Linear $\pi$-Conjugated Systems. Chemical Reviews, 97, 173-206. https:/doi.org/10.1021/cr950257t

[17] Yamamoto, T., Arai, M., Kokubo, H. and Sasaki, S. (2003) Copolymers of Thiophene and Thiazole. Regioregulation in Synthesis, Stacking Structure, and Optical Properties. Macromolecules, 36, 7986-7993. https:/doi.org/10.1021/ma030167n

[18] Yamamoto, T., Komarudin, D., Arai, M., Lee, B.-L., Suganuma, H., Asakawa, N., Inoue, Y., Kubota, K., Sasaki, S., Fukuda, T. and Matsuda, H. (1998) Extensive Studies on $\pi$-Stacking of Poly(3-alkylthiophene-2,5-diyl)s and Poly(4-alkylthiazole-2,5-diyl)s by Optical Spectroscopy, NMR Analysis, Light Scattering Analysis, and X-Ray Crystallography. Journal of the American Chemical Society, 120, 2047-2058. https:/doi.org/10.1021/ja973873a

[19] Katayama, T., Nakatsuka, S., Hirai, H., Yasuda, N., Kumar, J., Kawai, T. and Hatakeyama, T. (2016) Two-Step Synthesis of Boron-Fused Double Helicenes. Journal of the American Chemical Society, 138, 5210-5213. https:/doi.org/10.1021/jacs.6b01674 
[20] Bruker AXS Inc. (2009) APEX2 Version 2009.9.

[21] Bruker AXS Inc. (2009) SAINT Version 7.68A.

[22] Sheldrick, G.M. (2008) XPREP Version 2008/2. Bruker AXS Inc., Madison.

[23] Sheldrick, G.M. (2008) SADABS, Version 2008/1. Bruker AXS Inc., Madison.

[24] Sheldrick, G.M. (2008) SHELX Version 2014/6. Acta Crystallographica, A64, 112-122. https:/doi.org/10.1107/S0108767307043930

[25] Halgren, T.A. (1996) Merck Molecular Force Field. I. Basis, Form, Scope, Parameterization, and Performance of MMFF94. Journal of Computational Chemistry, 17, 490-519. https:/doi.org/10.1002/(SICI)1096-987X(199604)17:5/6<490::AID-JCC1>3.0.CO;2-P

\section{Appendix A. Supplementary Material}

CCDC no. 1010570 for the compound 3a and 1010571 for the compound $3 b$ contain the supplementary crystallographic data. The data can be obtained free of charge via www.ccdc.cam.ac.uk/data request/cif by e-mailing data request@ccdc.cam.ac.uk, or by contacting The Cambridge Crystallography Data Centre, 12 Union Road, Cambridge, CB2 IEZ, UK. Fax: +44(0) 1223-336033.

Submit or recommend next manuscript to SCIRP and we will provide best service for you:

Accepting pre-submission inquiries through Email, Facebook, LinkedIn, Twitter, etc. A wide selection of journals (inclusive of 9 subjects, more than 200 journals)

Providing 24-hour high-quality service

User-friendly online submission system

Fair and swift peer-review system

Efficient typesetting and proofreading procedure

Display of the result of downloads and visits, as well as the number of cited articles

Maximum dissemination of your research work

Submit your manuscript at: http://papersubmission.scirp.org/

Or contact csta@scirp.org 